\section{The Marimbá Field in Well a Turbidite Reservoir Petrophysical Characterization}

Mendes I. S. ${ }^{1}$, UFF, Ribeiro G. S, UFRJ ${ }^{1}$, Lonardelli J. ${ }^{2}$, Petrobras

\section{Copyright 2018, SBGf - Sociedade Brasileira de Geofísica}

Este texto foi preparado para a apresentação no VIII Simpósio Brasileiro de Geofísica, Salinópolis, 18 a 20 de setembro de 2018. Seu conteúdo foi revisado pelo Comitê Técnico do VIII SimBGt, mas não necessariamente representa a opinião da SBGf ou de seus associados. É proibida a reprodução total ou parcial deste material para propósitos comerciais sem prévia autorização da SBGf.

\begin{abstract}
A critical interpretation of the complex reservoirs such as turbidite systems. Analysis of these profiles in conjunction with reservoir rock sample descriptions has been shown to be an effective method. Its use goes beyond hydrocarbon identification and is used in the petrophysical calculations using a basic suite of gamma rays, neutron porosity, density, resistivity, sonic and caliper logs. Also in the exploratory phase, it is possible to make calculations, porosity, saturation, permeability and net pay, enabling better knowledge of the reservoir potential. When turbidite reservoirs have clay intercalations, if they are neglected, then this causes another source of uncertainty.
\end{abstract}

\section{Introduction}

Geophysical well profiling is the most commonly used technique to obtain in situ well data. This yields a wealth of information from within the hydrocarbon prospected area. The obtained data is important to determine the hydrocarbon-laden sand layers in the turbidite reservoir. Turbidite complexes are considered potential hydrocarbon producers due to the interspersed sandstone and clay layers. This study demonstrates the feasibility of identifying turbidite reservoir complexes and their petrophysical parameters in the well profiles. For this purpose, the lithological, resistivity and density and neutronic profiles were used. The methodology used involved the formation diagenetic processes analysis of these reservoirs to identify the interspersed sandstone and clay layers; the lithology of the geological facies forming turbidites that appeared with different thicknesses ranging from thick packs of sandstones to fine amalgam layers and interspersed with layers of shales, marls and silts. The profile records were analyzed using TechLog® software, where important rock/fluid data were obtained and correlated with the rock descriptions provided by the National Petroleum Agency (Agência Nacional do Petróleo ANP), Campo de Marimbá - Campos Basin, which confirms the need for petrophysical studies based on the profile curves. From the profile analysis, the petrophysical parameters of porosity, permeability, clay volume and economic thicknesses (net pay) can be determined. From the profile curves data correlation it can be concluded that the field data and the petrophysical study collaborate with the reservoir generating conditions characterization and the necessary parameters to analyze the productive life of the wells. This can then be used for an overview of the field as a whole. From the petrophysical results obtained from the Campo de Marimbá Well A profiles, the average porosity obtained was $28 \%$, average saturation $15 \%$, average permeability $300 / 600 \mathrm{mD}$ and net pay $27 \mathrm{~m}$. It was observed that factors such as clayey, Well instability in shale layers or thin sandstone/shale intercalations and filtrate type interfered directly or indirectly in the calculations. Profile use to identify hydrocarbon reservoirs is undoubtedly a great interpretation tool and should be carefully analyzed, especially in complex reservoirs such as turbidite systems.

\section{Metodology \\ Area Location}

The Marimbá field is located in the South of the Campos Basin between the Liguado and Carapeba Fields, approximately $80 \mathrm{~km}$ from Cable of São Tomé in water depths ranging from 320 to 780 m (Horschultz et al., 1980)

(Figure 1).

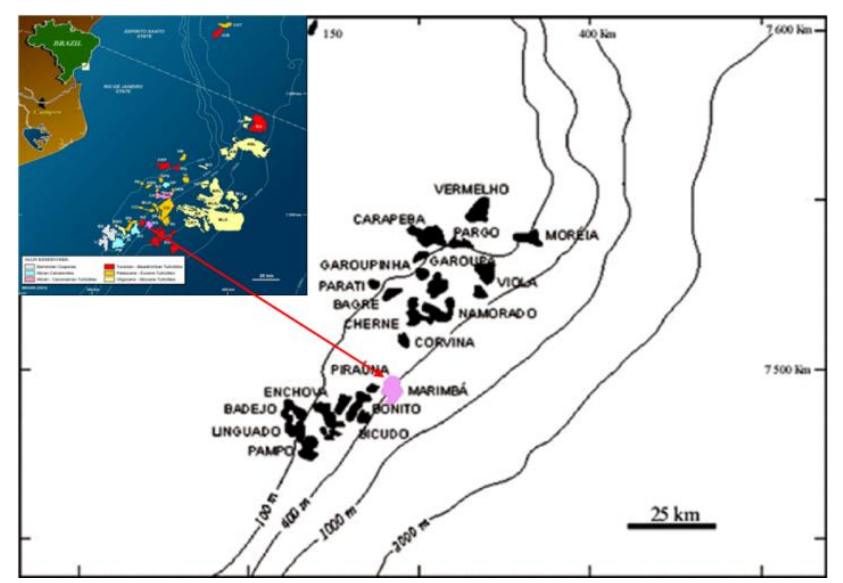

Figure 1 - Campo de Marimbá location map in the Campos Basin (Milani, E. J. Rev Bras. Geof. Vol.18 no.3 - São Paulo 2000.)

\section{Well A Zones Definition}

After loading the gamma ray (GR) caliper and sonic contours on the TechLog $\circledast$, the profiles were analyzed with the field lithological descriptions in the composite profile, the zones being defined based on the gamma ray and sonic features that clearly characterize the lithological changes. Five distinct zones were defined: $A, B, C, D$ and $E$, where $C$ is characterized as a reservoir (Figure 2). The zone $A$ is characterized by intense interlaced / interspersed lithology (shales, marls, sandstones, calcilutites and sandstones) with carbonate and clayey contributions in the same proportions with mean gamma rays of $65^{\circ} \mathrm{API}$. Zone $B$ presents a higher gamma ray trend (105 $\left.{ }^{\circ} \mathrm{API}\right)$, characterized by micaceous and fissile shales grading from marls at the base as shown by the graded increase of carbonates at the base with some thin sandstone and calcarenite interspersions. Its geometry varies from bell to funnel. In layer $C$ there is a drop of gamma rays with a 40 - API trend with peaks of gamma rays along the interval, where thick and thin layers of sandstone interspersed the layers of shale occur. In zone $D$ the gamma rays return to the zone B shale trend, with intercalated thin layers of sandstone interspersed with the shale. Zone $\mathrm{E}$ is marked 
with the gamma ray drop characterized by the interspersion of marl, calcilutites and calcarenites.

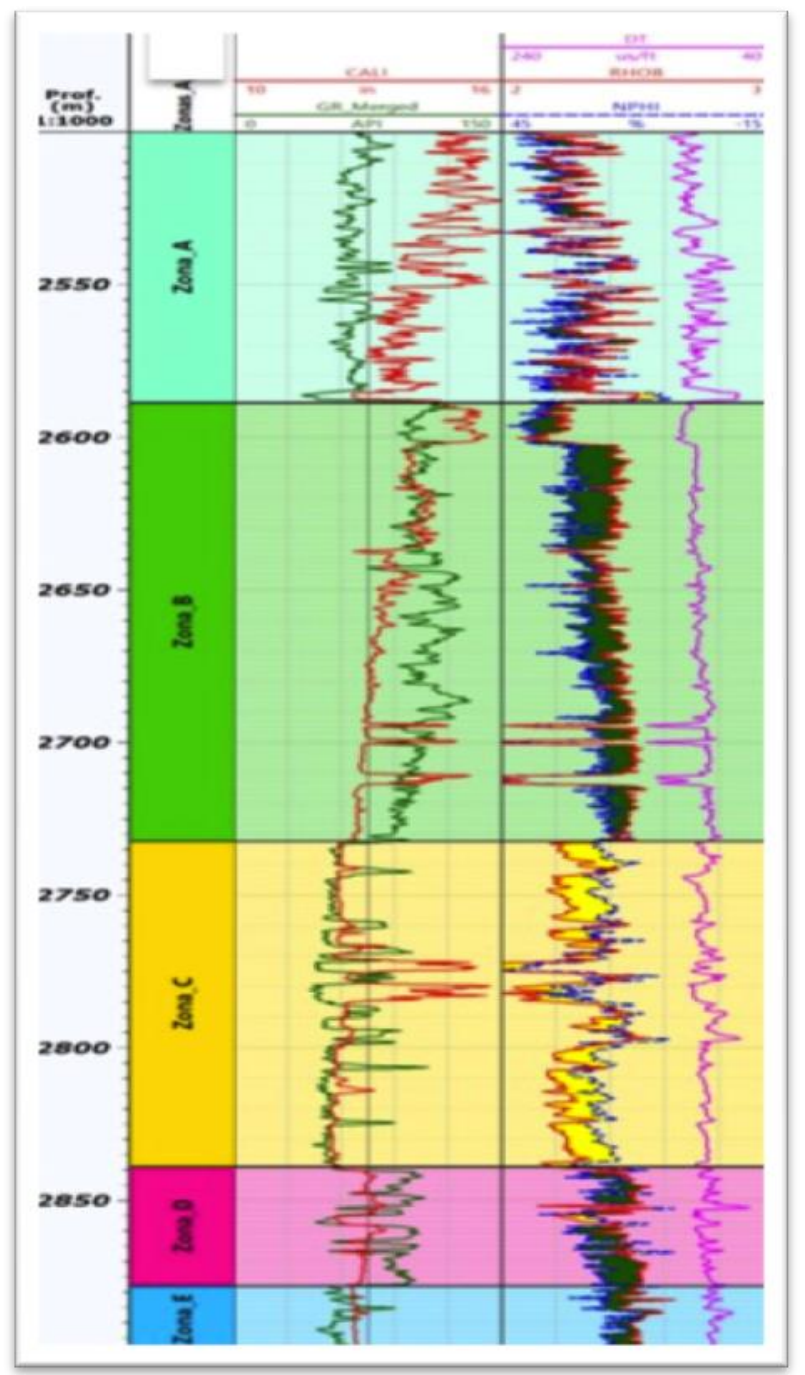

Figure 2 - Zone Plot with the tracks: 1) Depht (m), 2) gamma ray (GR) and caliper (CAL), 3) sonic (DT), composite with neutronic porosity (NPHI) and density (RHOB).

\section{Well A Turbidite Reservoir}

The zone $\mathrm{C}$ reservoir was characterized as formed by thick to thin layers of sandstones interspersed with layers of shale. The histogram (Figure 3 ) shows the sandstone frequencies between $40-85^{\circ} \mathrm{API}$ (yellow columns) and for the shale $70-110^{\circ} \mathrm{API}$ (blue columns). The higher trend of gamma rays in the sandstone is due to its quartzfeldspathic composition, as well as dispersed clays where there is a dispersion of yellow dots outside the sandstone line and near the carbonate line (calciferous cement). The blue dots are the layers of shales with a carbonaceous matrix.

\section{Results}

\section{Petrophysical Reservoir Analysis With Conventional Profiles}

The petrophysical calculations for this study were based on the Caliper, Gamma Ray, Density, Neutronic Porosity, Sonic and Resistivity profiles for Well A. The calculations were only made in Zone $\mathrm{C}$ where the reservoir was characterized. The profile quality control was based on "quick looks" where some quick calculations are made to obtain a first approximation of the saturation ( $\mathrm{Sw}=1$ - Shc). Gas effects were not observed in the cross-plot no a mirror effect in the density and neutronic porosity pair.

The clay volume calculation plot (Figure 3 ) in the sandstone layers was very low - less than $17 \%$ clay. This percentage is due to the dispersed clays. The shale layers interlaced / interspersed the reservoir sandy layers are well defined in the gamma ray and clay volume curve. This can even be compared with the clay volumes of zone $B$ (carbonate shale) and D (carbonate silt shale). The matrix density (RHOMA) for the sandstone layers averaged $2.67 \mathrm{~g} / \mathrm{cm} 3$ and for the shale layers the mean was $2.77 \mathrm{~g} / \mathrm{cm} 3$.

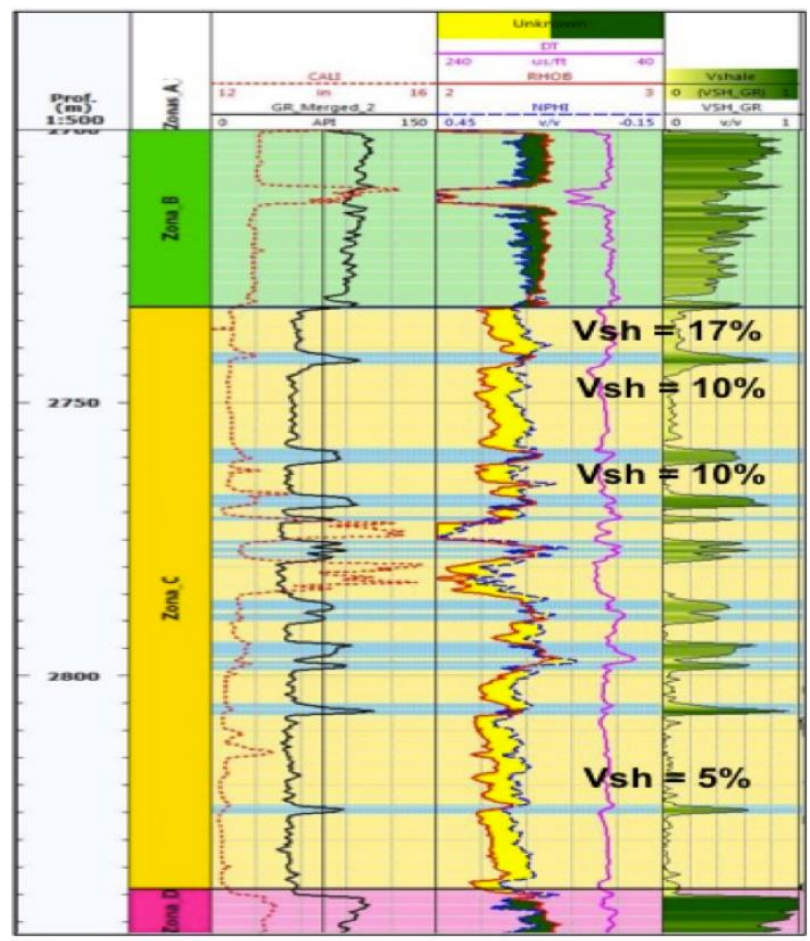

Figure 3 - Plot with the clay volume calculation. Tracks: 1) Depth, 2) Zones, 3) gamma ray curve (GR) and caliper (CAL), 4) sonic (DT), neutronic porosity (NPHI) and density (RHOB), 5) Calculated clay volume, 6 ) matrix density (RHOMA).

\section{Porosity}

The effective porosity calculation (Figure 4) in the sand has an average of $27 \%$, and the effective porosity is close to the total porosity indicating that the pores are interconnected; the reservoir has excellent permoporous characteristics. The shale layer porosity is considerable; however the neutronic porosity profile is influenced by the clays that have high hydrogen levels due to irreducible (adsorbed) water attached to the clay mineral surfaces, or in the clay structures due to the clay cation exchange 
capacity, with the excess of negative charges existing in the structure of the exchanger leading to ion compensation.

This property results from the imbalance of electric charges caused by the isomorphic substitutions of broken bonds at the particle edges which are terminated by $\mathrm{OH}$ group, and the interaction of $\mathrm{H}+$ ions, the exchangeability will depend on the crystal size and the exchangeable clay cations type.

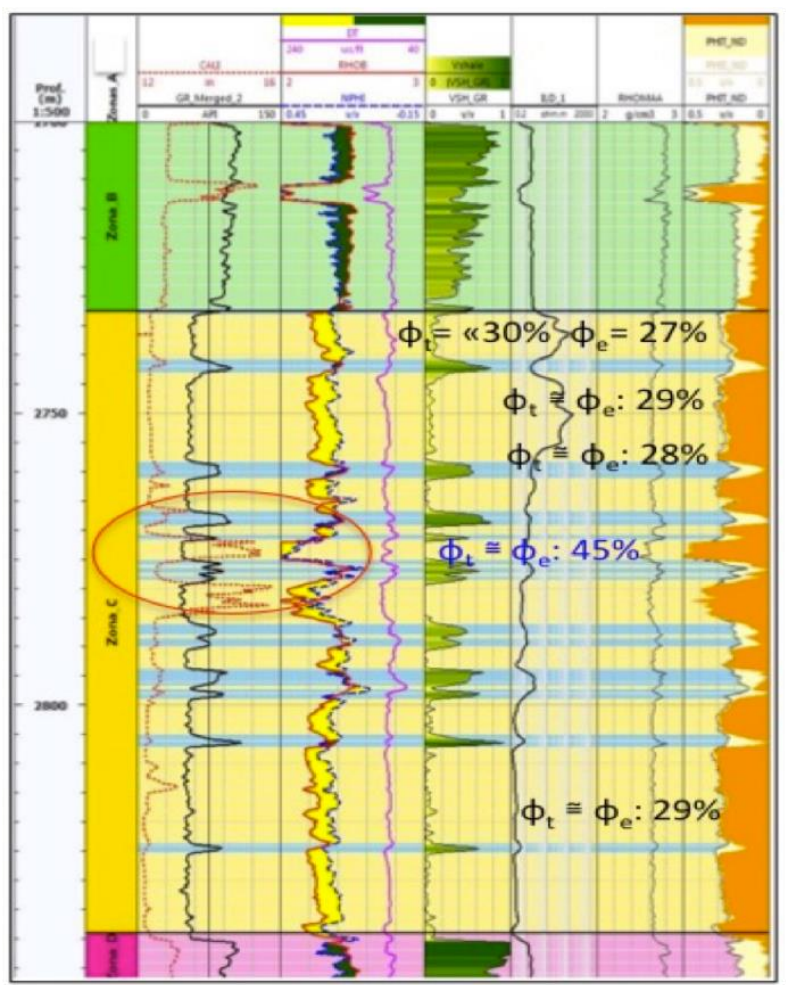

Figure 4 - Plot of effective and total porosity. Tracks: 1) Depth, 2) Zones, 3) gamma ray (GR) and caliper (CAL) curve, 4) Clay volume, 5) Sonic (DT), neutronic porosity (NPHI) and density (RHOB), 6) deep resistivity (ILD), 7) mean density of the matrix (RHMA), 8) Effective (PHIE) and total (PHIT) porosity.

There are high effective porosity sand layers with around $45 \%$ in the intervals from 2770 to $2785 \mathrm{~m}$ which cannot be taken into account. This is because the $121 / 4$ "diameter Well had severe general collapses in the shale and thin shale/sandstone interspersed layers, as observed in the caliper increase (red ellipse in figure 6), this affects the registers of the profiles. The tool has more contact with the drilling fluid than with the rock, influencing, mainly the readings of the neutronic porosity (NPHI) and density (RHOB) tools and consequently in the porosity calculation. The shales have an average porosity frequency of $10 \%$ up to $20 \%$, due to the clay effect in the neutronic porosity profile (irreducible water of the clays), whereas the sandstone has a high average porosity frequency of $25 \%$. Porosities above $35 \%$ are not being considered due to the collapses affecting the density and neutronic porosity (coulumns red) On the other hand, the porosities below $10 \%$ are with calciferous cement.

\section{Saturation}

Water saturation was calculated in the TechLog® program, with a minimum resistivity of $0.05 \mathrm{ohm} . \mathrm{m}$, temperature of $172^{\circ} \mathrm{F}$, shale resistivity of 2 ohm.m, Vsh> $0 ; n=2$ and $m$ $=1,81$ because we did not have rock samples for laboratory tests and without the clay type distinction the saturation was calculated from the Simandoux equation (1963)

The formation geothermal gradient and salinity during cable profiling were respectively $34.5^{\circ} \mathrm{F}$ and $150.000 \mathrm{ppm}$ in the water saturated zone, which uses the calculated clay volume to replace $B Q v(B=$ equivalent conductance of clay cation $(\mathrm{mS} / \mathrm{m})$ and $\mathrm{Qv}=$ counter ion concentration (meq/gm)). The drilling fluid was water based with 34,650 ppm salinity. The composite profile (ANP provided data) shows the water saturation area and hydrocarbons well defined by the two shallow and deep resistivity curves (Figure 5).

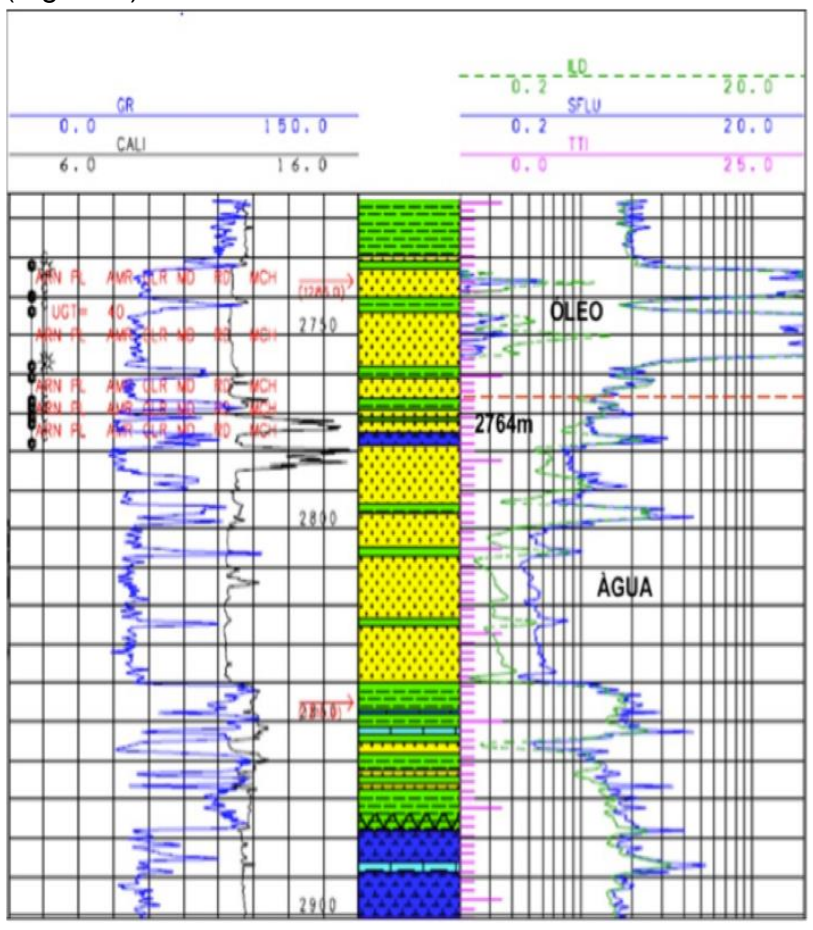

Figure 5 - Composite profile tracks: 1- Gamma rays, 2 - Lithology, 3 - deep (ILD) and shallow (SFLU) resistivity curves. The dashed red line at the depth of $2770 \mathrm{~m}$ marks the division between hydrocarbon-saturated and water-saturated zones.

The oil-saturated sandstone layers show the deep resistivity curve (ILD) with a reading higher than the shallow curve (SFLU) indicating the presence of hydrocarbons The layers of sandstone saturated with oil has a deep resistivity curve (ILD) with highest reading the shallow curve (SFLU) indicating the presence of hydrocarbons in the interval below the dotted line in red. At $2764 \mathrm{~m}$ depth the resistivity curves are inverted, with the shallow (SFLU) reading higher than the deep (ILD) indicating that the zone is saturated with salt water, as the drilling fluid is salt water based. These oil-saturated layers are identified as: 1 - layer from 2732.6 to $2741 \mathrm{~m}$; 2 - layer from 2743 to $2758.6 \mathrm{~m}$ and 3 - layer from 2761 to $2764 \mathrm{~m}$ a possible transition zone with the water saturated layers: 4 layers from 2769.4 to $2770.9 \mathrm{~m}$, and 5 makes up all the layers below $2764 \mathrm{~m}$ depth in the water and oil contact . 
In the composite profile and the saturation calculation plot, note layer 1 with hydrocarbon saturated sandstone has a slightly lower resistivity than layer 2 . This variation is possibly due to the adjacent shale layer interference, as the clayiness can decrease the resistivity as a function of the clay pores and/or clay minerals that are filled by water. These have the ability to exchange cations contained in this water (CEC), producing a decrease of the electrical registries and increasing their conductivity, thus affecting the resistivity profile registry. In a very clayey reservoir, this can even quantitatively underestimate the reservoir. The sandstone layer 4 with $45 \%$ porosity and $45 \%$ water saturation was highlighted to show the influence of the intervals with a collapsed caliper (blue dotted hyperbole in Figure 6) in the profile registrations especially, in the neutronic porosity (NPHI), density $(\mathrm{RHOB})$ profiles used to calculate porosity. This leads to erroneous calculations in these intervals overestimating porosity and consequently saturation. Hence it is important to do profile interpretation when characterizing the hydrocarbon bearing zones.

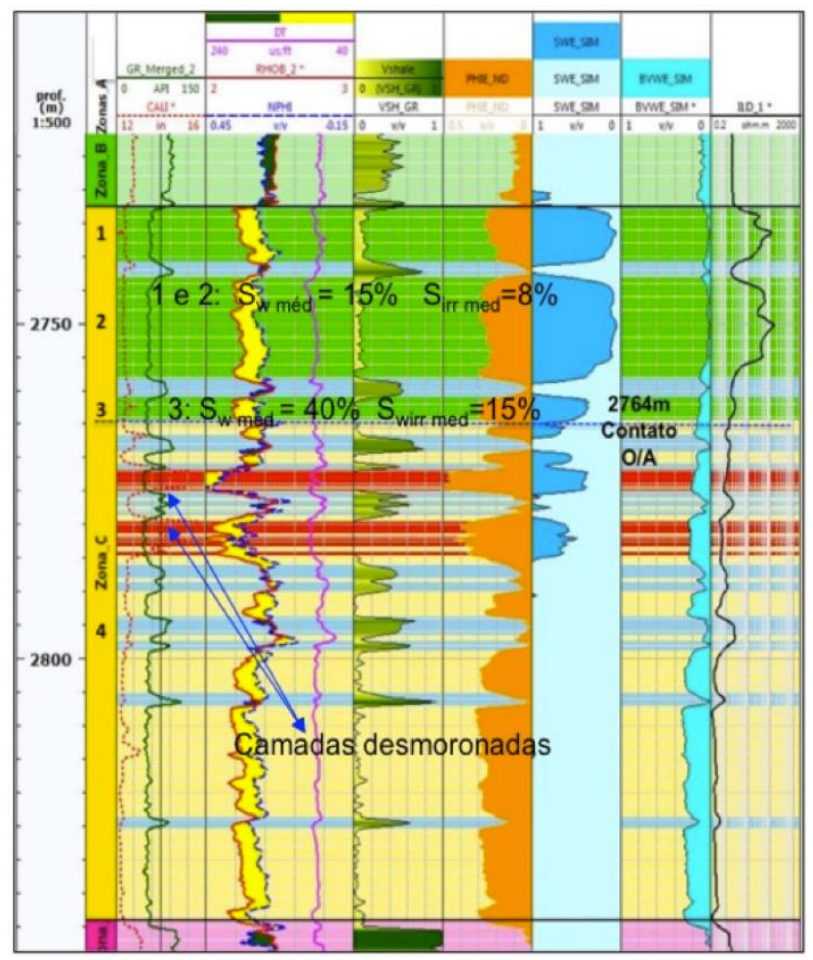

Figure 6 - Plot with saturation calculation. Tracks: 1 - depth (m), 2 - zones, 3 - Gamma rays (GR) and Caliper (Cal), 4 Clay volume $\left(\mathrm{V}_{\mathrm{sh}}\right), 5$ - Density (RHOB), neutronic (NPHI) and sonic (DT), 6 - Saturation $\left(S_{w}\right), 7$ - Deep resistivity (ILD). Layers 1, 2 and 3 are hydrocarbon saturated intervals, the dotted arrows point to the resistivity difference between layers 1 and 2. Layer 4 watersaturated, has high porosity due to the failures of neutronic porosity profiles and density as a function of wellbore collapse.

The average saturation in layers 1 and 2 was $15 \%$ and the mean effective porosity $27 \%$ with irreducible saturation (BVWE) around 15\%. In these sandstones layers there are intercalated shales at respectively: 2741-2743m and $2758.8-2761 \mathrm{~m}$. In these layers small collapses can be noted as shown in the Well diameter increase in the caliper profile.

\section{Permeability}

The permeability was calculated according to the Coates equation, considering the effective porosity, total porosity and irreducible water saturation. The average permeability in Well $A$ was $300 \mathrm{mD}$, the plot with the saturation calculation shows the permeability variation along the hydrocarbon-saturated layers in (1,2 and 3). Note: The petrophysical characteristics peak of the hydrocarbonsaturated (light green) sandstone layers (Figure 7).

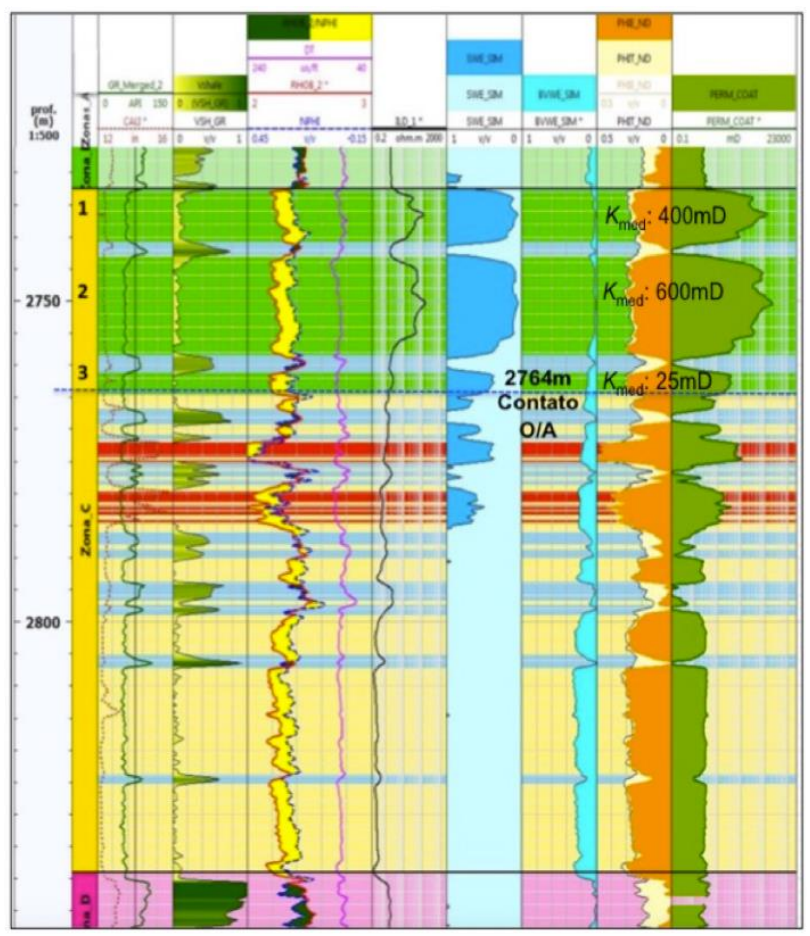

Figure 7 - Tracks: 1 - depth, 2 - zones, 3 - Gamma rays (GR), 4 Porosities Total (PHIt) and effective (PHle) - 5) Irreducible water saturation and 6 -Permeability (K). Maximum porosity peaks (light green), saturation, irreducible water and permeability.

This section clearly demonstrates how the calculations were made: The oil-saturated layers (blue) and the layers where the wellbores had collapsed (brown) were selected in the plot, generating the permeability versus effective porosity cross-plot. It was noted the hydrocarbon-bearing layers confirmed porosities between 20 and $27 \%$ and permeabilities of 10 to $1500 \mathrm{mD}$ on average $500 \mathrm{mD}$. 


\section{Net Pay}

The Cutoffs used were: $\phi>12 \%$; Sw $<60 \%$; Vsh $<50 \%$. The economic thickness calculation corroborated the porosity, saturation and permeability calculations, identified in the turbidite sandstone layers 1,2 and 3, the first 3 layers of the reservoir carrying hydrocarbons (Figure $8)$. The hydrocarbon saturated layers 1 and 2 presented higher thicknesses, respectively 8,4 and 15.3 meters than the thinner layer 3 totally net pay, just 3,30 meters. Considering the latter was not only the thinnest, also, like layer 1, the adjacent shale layers influenced it. Although layer 4 is computed, it is not considered an economical layer, as this layer, is in a water-saturated zone, as shown in the composite profile. It also had the Well diameter altered due to the wellbore collapse, as observed in the caliper profile, and adversely influenced the neutronic porosity and density profiles.

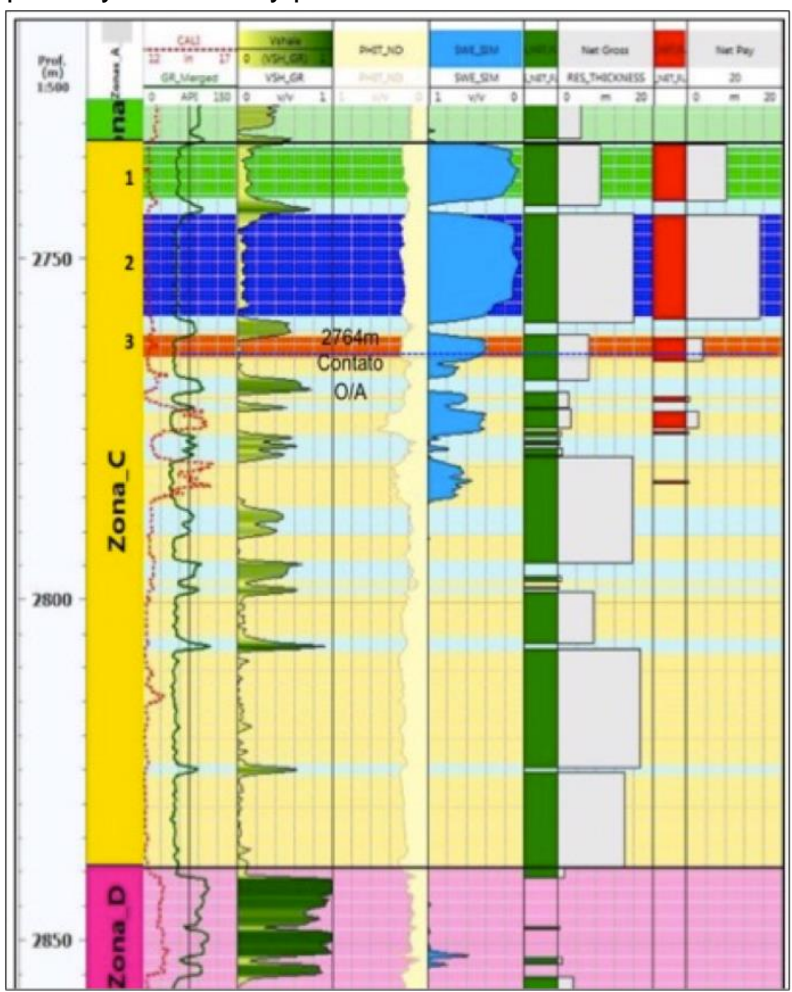

Figure 8 - Net pay Tracks: 1 Depth (m), 2 Zones; 3 Caliper/gamma rays $(\mathrm{GR}), 4$ clay volume $\left(\mathrm{V}_{\mathrm{sh}}\right), 5$ - porosity effective (PHIE), 6 water saturation $\left(S_{w}\right), 7 / 8$ net gross, $9 / 10$ - Net Pay.

\section{Conclusions}

The use of geophysical Well profile analysis together with field rock descriptions in the basic petrophysical calculations of Well A reservoir in the Marimbá field was seen as satisfactory. The profile analysis took into account the rock cutting sample descriptions being composed of arkosic sandstone, clayey (dispersed clays) intercalated to the shales. As a result, the average porosity of $27 \%$, average saturation $15 \%$, average permeability of $500 \mathrm{mD}$ and economic thickness (net pay) of $27 \mathrm{~m}$ were obtained. Factors that interfered directly or indirectly in these calculations were taken into account (Figure 15) the plot that resulted from instability problems the identification of hydrocarbon reservoirs is undoubtedly a great tool mainly during drilling, but the interpretation must be careful, especially in complex and clayey reservoirs such as turbidites which, in addition to intercalated shale layers, may have laminar, structural and dispersed clays that can close the pore throat during production, it is also necessary to consider radioactive or conductor minerals (feldspar, glauconite, pyrite etc.) or the profiling environment (type of drilling fluid, fluid additives) and Well instability problems (wellbore collapsing). It is necessary to know how to recognize these interferences, to not misinterpret, overstate or underestimate the sandstone layers interspersed in layers of shales.

\section{Acknowledgment}

The authors would like to thank the National Petroleum Agency for the data provided, Fluminense Federal University and the Federal University of Rio de Janeiro for space and support.

\section{Referências Bibliográficas}

Bayão, P. C., 2014. Caracterização Petrofísica do Campo de Namorado a Partir de Perfis de Poço. TCC - UFF.

Becerra, G. G., Modenesi, A. P., LISBOA, E. E. A., Ferreira, D. M. and REIS, L. C., 2011. Ajuste de histórico e previsão sob incerteza, uma aplicação no Campo de Marimbá. Boletim Técnico da Produção de Petróleo, v.5, n.2, p.7-44.

Bruhn, C. H. L. \& Walker, R. G. 1995. High-resolution stratigraphy and sedimentary Evolution of coarse-grained canyon-filling turbidites from the Upper Cretaceous Transgressive Megassequence, Campos Basin, Offshore Brazil. In: Journal of Sedimentary Research, Vol. B65, n.4, p. 426-442.

Bruhn, C. H. L, 1998. Deep Water reservoirs from the eastern Brazilian rift and Passive margin basins. Petroleum Geology of Rift and Passive Margin Turbidite Systems: Brazilian and Worldwide Examples. In: 1998 AAPG International Conference \& Exibition, Rio de Janeiro, v. Course\#6.

Bruhn, C. H. L, and Petroleum Geologists. Contrasting Types of Oligocene / Miocene, Giant Turbidite Reservoirs from Deep Water Campos Basin, Brazil, 2001. The American Association.

Contreras, S. A.; Cáceres and Castro, J. C. Metodologia para determinar parâmetros petrofísicos de corte em um campo de petróleo: o caso Socororo, bacia do Oriente, Venezuela. Rem: Rev. Esc. Minas [online]. 2012, vol. 65, n. 3, pp. 305-312. ISSN 0370-4467.

D’Avilla, R. S. F.; Arienti, L. M.; Aragão, M. A. N. F.; Vesely, F. F.; Santos, S. F.; Voelcker, H. E.; Viana, A. E.; Kowsmann, R. O.; Moreira, J. L. P.; Coura, A. P.; Paim, P. 
S. G.; Matos, R. S. e Machado, L. C. R. Ambientes Marinhos Profundos: Sistemas turbidíticos, Ambientes de Sedimentação Siliciclástica do Brasil, 2007. p. 236-263.

Guimarães, M. S.; Denicol, G. Avaliação e caracterização de reservatórios laminados: comparação entre as ferramentas convencionais e o perfil de indução multicomponente - RBG. v.38, n.1 - supl.1 - São Paulo mar. 2008.

Horschutz, P. M. C.; Freitas, L. C. S.; Stank, C. V.; Barroso A. S. and Cruz, W. M. The Linguado, Carapeba, Vermelho and Marimba Giant fields Campos Basin, Offshore Brazil. Id: A014 (1992). Pg. 137 - 153.

Milani, E. J.; Brandão, J. A. S. L.; Zalán, P. V. \& Gamboa, A. P. Petróleo na Margem Continental Brasileira: Geologia, Exploração, Resultados e Perspectivas - Revista Brasileira de Geofísica, Vol. 18(3), 2000.

Mutti, E., Bertnoulli, D., Lucchi, F. R. and Tinterril, R. (2009), Turbidites and turbidity currents from Alpine 'flysch' to the exploration of continental margins. Sedimentology (2009), 56: 267-318. doi:10.1111/j.13653091.2008.01019.x

Omoboriowo, A. O.; Chiadikobi; K. C. and Chiaghanam; O. I. Depositional Environment and Petrophysical Characteristics of "LEPA" Reservoir, Amma Field, Eastern Niger Delta, Nigeria, pag. 46-47.

Ribeiro, 2015 - notas de aula UFRJ- Curso de Petrofisica -Topicos Especiais Aula 6.

SERRA, O. \& L., Well Logging - Data Acquisition and Applications. Ed. Serralog, Méry Corbon, França, 2004. cap. $1,10,26,31$.

Schlumberger 1987. Log interpretation principles/applications. N.Y., Schlumberger Ltd. pg 198, 2009 edition.

Snider, R. M. Worldwide Examples of Low Resistivity Pay - Huston Geological Society Bulletin - February.

Walker, R. G., 1978. Deep water sandstone facies and ancient submarine fans: Models for exploration for stratigraphic traps. Bull Am. Assoc. Petrol Geol, 62:932966. 